\title{
Substitution of histidine 30 by asparagine in manganese superoxide dismutase alters biophysical properties and supports proliferation in a K562 leukemia cell line
}

\author{
Rosalin Bonetta ${ }^{1,8}$ (1) Gary J. Hunter ${ }^{2} \cdot$ Chi H. Trinh ${ }^{3} \cdot$ Tomasz Borowski $^{4} \cdot$ Anthony G. Fenech $^{5} \cdot$ Maria Kulp $^{6}$. \\ Leandro C. Tabares ${ }^{7} \cdot$ Sun Un ${ }^{7}$. Thérèse Hunter ${ }^{2}$
}

Received: 29 September 2020 / Revised: 22 April 2021 / Accepted: 23 April 2021 / Published online: 21 May 2021

(c) The Author(s) 2021

\begin{abstract}
We have generated a mutant of $C$. elegans manganese superoxide dismutase at histidine 30 by site-directed mutagenesis. The structure was solved at a resolution of $1.52 \AA$ by X-ray crystallography (pdb: 6S0D). His30 was targeted, as it forms as a gateway residue at the top of the solvent access funnel to the active site, together with Tyr34. In the wild-type protein, these gateway residues are involved in the hydrogen-bonding network providing the protons necessary for the catalytic reaction at the metal center. However, biophysical characterization and cell viability experiments reveal that a mutation from histidine to asparagine in the $\mathrm{H} 30 \mathrm{~N}$ mutant modifies metal selectivity in the protein, favoring the uptake of iron over manganese in minimal media conditions, alters active-site coordination from the characteristic trigonal bipyramidal to octahedral geometry, and encourages cellular proliferation in K562 cells, when added exogenously to the cells.
\end{abstract}

Keywords Proteins $\cdot$ Superoxide dismutase $\cdot$ Structural modelling $\cdot$ Spectroscopy $\cdot$ Biophysics $\cdot$ X-ray crystallography

Special Issue: COST Action CA15126, MOBIEU: Between atom and cell.

Rosalin Bonetta

r.bonetta@qmul.ac.uk

1 Centre of Molecular Medicine \& Biobanking, University of Malta, Msida, Malta

2 Department of Physiology and Biochemistry, Faculty of Medicine and Surgery, University of Malta, Msida, Malta

3 Astbury Centre for Structural Molecular Biology, Institute of Molecular and Cellular Biology, University of Leeds, Leeds, UK

4 Jerzy Haber Institute of Catalysis and Surface Chemistry, Polish Academy of Sciences, Krakow, Poland

5 Department of Clinical Pharmacology and Therapeutics, Faculty of Medicine and Surgery, University of Malta, Msida, Malta

6 Department of Chemistry, Tallinn University of Technology, Tallinn, Estonia

7 Institute for Integrative Biology of the Cell (I2BC), Université Paris-Saclay, CEA, CNRS, 91198 Gif-sur-Yvette, France

8 Present Address: Barts and the London, School of Medicine and Dentistry, QMUL, Victoria, Malta

\author{
Abbreviations \\ IPTG Isopropyl $\beta$-D-1-thiogalactopyranoside \\ H3ON MnSOD-3[H30N] \\ H30F MnSOD-3[H30F] \\ CD Circular dichroism \\ MD Molecular dynamics \\ HFEPR High-field electron paramagnetic resonance \\ SEM Standard error of the mean
}

\section{Introduction}

Eukaryotic manganese superoxide dismutase (SOD, EC 1.15.1.1) is a nuclear-encoded protein that is synthesized with an $\mathrm{N}$-terminal leader sequence that targets it to the mitochondrion. The mature homotetrameric MnSOD resides in the mitochondrial matrix where it provides protection against the superoxide radicals generated by the electron transport chain (Sheng et al. 2014). The nature of the MnSOD catalytic reaction illustrates the dual role this enzyme plays as both an antioxidant and a modulator of the redox status. During catalysis, the cyclic reduction and oxidation of the active site manganese cofactor is accompanied by the dismutation of two superoxide anions to molecular 


$$
\begin{array}{lll}
\mathrm{Mn}^{3+}+\mathrm{O}_{2} \cdot \bullet & \rightarrow & \mathrm{Mn}^{2+}+\mathrm{O}_{2} \\
\mathrm{Mn}^{2+}+\mathrm{O}_{2}^{-} \bullet+2 \mathrm{H}^{+} & \rightarrow & \mathrm{Mn}^{3+}+\mathrm{H}_{2} \mathrm{O}_{2}
\end{array}
$$

Scheme 1 Dismutation by SOD

oxygen and hydrogen peroxide (Scheme 1) (Bull et al. 1991; McAdam et al. 1977).

Consequently, the rate at which the superoxide is removed and the subsequent release of hydrogen peroxide into the immediate environment contribute to the transient redox status of the cell. Since cellular membranes are highly permeable to hydrogen peroxide and superoxide can move from the inter-membrane space to the cytoplasm via voltage dependent anion channels (VDAC) (Han et al. 2003), changes in the ratio of superoxide to hydrogen peroxide have far-reaching consequences for the cell.

Furthermore, the degree of metalation with the manganese cofactor during the folding of nascent protein influences the activity of MnSOD and appears to be optimized by HSP60 (Bie et al. 2016; Hunter et al. 2015; Hunter and Hunter 2013; Magnoni et al. 2014).

The C. elegans nematode produces two distinct mitochondrial MnSODs; MnSOD-2 and MnSOD-3. Mnsod-2 is expressed constitutively throughout all the life stages of nematode while the Mnsod-3 gene is a target of DAF-16/ FOXO and is induced during the dauer stage in response to stressful environmental conditions (Honda and Honda 1999). Interestingly, this protein is also produced by the longevity mutants DAF-2 and AGE-1, which have altered insulin/IGF-1 signaling. Despite the high structural homology amongst the active sites of studied eukaryotic MnSODs, there are differences in their kinetic profiles that may influence the cellular response to the redox status. The MnSOD catalytic mechanism has been described by the McAdam scheme as four reactions that occur via two simultaneous pathways, the outer and the inner-sphere pathways (McAdam et al. 1977) (Scheme 2).

The outer-sphere pathway, represented in Scheme 2 by reaction 1 and 2 , reduces superoxide to hydrogen peroxide instantaneously under normal conditions of superoxide levels. When the superoxide levels are elevated, reaction 3 of the inner-sphere pathway results in the formation of the Mn-peroxy complex that inhibits the enzyme. The rate of dissociation of this complex and the release of the hydrogen peroxide product is described by $k_{4}$. The gating ratio $k_{2} / k_{3}$ is used to determine the favored pathway and whether the production of hydrogen peroxide is very fast $\left(k_{2} / k_{3}>1\right)$ or whether the enzyme is product-inhibited $\left(k_{2} / k_{3}<1\right)$ (Hearn et al. 1999; Hsu et al. 1996). Known prokaryotic MnSODs tend to function via the instantaneous outer-sphere pathway (Sheng et al. 2012).

While human and C. elegans MnSOD are structurally very similar, the product dissociation constant $\left(\mathrm{k}_{4} 120 \mathrm{~s}^{-1}\right)$ of the human enzyme is lower than that of the C. elegans MnSOD-3 $\left(k_{4} 300 \mathrm{~s}^{-1}\right)$ (Hunter et al. 2015). This may be a mechanism adopted by human cells to prevent the production of high levels of hydrogen peroxide when superoxide levels are elevated, reducing any signaling response to the hydrogen peroxide (Abreu and Cabelli 2010). His30 and Tyr34 are gateway residues, positioned at the top of the solvent access funnel to the active site. They participate in the hydrogen-bonding network that provides the protons necessary for the catalytic reaction at the metal center. By studying the effect of MnSOD-3 harboring His30 mutations on a K562 leukemia cell line, we tested whether the activity of MnSOD is a factor that controls the molecular switch between cellular proliferation and apoptosis.

The involvement of MnSOD in cancer development, progression, and prevention has been a contentious one as varying levels of MnSOD expression and activity have been associated with different cancer types during different stages of progression. Low levels of the enzyme appear to support transformation of normal cells, most likely as a consequence of ineffective antioxidant protection during early stage carcinogenesis (Dhar et al. 2011). However, the expression of Mnsod has been reported to increase during the establishment of an aggressive, invasive cancer phenotype (Connor et al. 2007). The activity of MnSOD also appears to determine the
Scheme 2 Mechanism of catalysis of MnSOD

$\begin{array}{clll}\mathrm{Mn}^{3+} \mathrm{SOD}\left(\mathrm{OH}^{-}\right)+\mathrm{O}_{2} \bullet & \rightarrow & \mathrm{Mn}^{2+} \mathrm{SOD}\left(\mathrm{H}_{2} \mathrm{O}\right)+\mathrm{O}_{2} \\ \mathrm{Mn}^{2+} \mathrm{SOD}\left(\mathrm{H}_{2} \mathrm{O}\right)+\mathrm{O}_{2} \bullet^{--} & \rightarrow & \mathrm{Mn}^{3+} \mathrm{SOD}\left(\mathrm{OH}^{-}\right)+\mathrm{H}_{2} \mathrm{O}_{2} \\ & k_{3} & \\ \mathrm{Mn}^{2+} \mathrm{SOD}\left(\mathrm{H}_{2} \mathrm{O}\right)+\mathrm{O}_{2} \bullet & \rightarrow & \mathrm{Mn}^{3+} \mathrm{SOD}\left(\mathrm{H}_{2} \mathrm{O}\right)\left(\mathrm{OO}^{2-}\right) \\ & k_{4} \mathrm{H}^{+} & \\ \mathrm{Mn}^{3+} \mathrm{SOD}\left(\mathrm{H}_{2} \mathrm{O}\right)\left(\mathrm{OO}^{2-}\right) & \rightarrow & \mathrm{Mn}^{3+} \mathrm{SOD}\left(\mathrm{OH}^{-}\right)+\mathrm{H}_{2} \mathrm{O}_{2}\end{array}$

(Reaction 1)

(Reaction 2)

(Reaction 3)

(Reaction 4) 
tumor-suppressor or tumor-promoter character of the enzyme (Dhar and St Clair 2012).

\section{Materials and methods}

\section{Reagents and cells}

All general-purpose chemicals and buffers were obtained from Sigma-Aldrich (Germany) and VWR International (Radnor, USA) and bacteriological media was from Oxoid (Basingstoke UK). The Quikchange II XL site-directed mutagenesis kit was supplied by Agilent Technologies (Santa Clara, Ca). The PureLink HQ plasmid mini prep kit and the Alexa Fluor ${ }^{\circledR} 488$ Annexin V/Dead cell Apoptosis Kit were purchased from Invitrogen (Waltham, MA). The Caspase-GIo 3/7, 8 and 9 Assay kits and the CellTiter-Glo ${ }^{\circledR}$ assay kit were from Promega (Madison, WI). All the oligonucleotides were synthesized by Bioneer (South Korea).

\section{Site-directed mutagenesis}

The cDNA of the $C$. elegans MnSOD-3 (protein is designated as MnSOD-3WT throughout), previously cloned into a pTrc99A expression system (Hunter et al. 1997), served as the template for site-directed mutagenesis utilizing the QuikChange II XL system. The following oligonucleotide pairs were used to replace histidine 30 with asparagine or phenylalanine, respectively (mutagenic bases are underlined).

H30N Forward: 5'- CTTCATCATCAAAAGAATCAT GCCACCTACGTG-3', H30N Reverse: 5'-CACGTAGGT GGCATGATTCTTTTGATGATGAAG-3', H30F Forward: 5'-GCTTCATCATCAAAAGTTTCATGCCACCTACGT GAAC-3, H30F Reverse: 5'-GTTCACGTAGGTGGCATG AAACTTTTGATGATGAAGC-3'.

Positive mutants were confirmed by sequencing using PKPro-5 (CTCGTATAATGTGTGGAATTGTGAGCGG) and PKTerm-5 (CCTGACCCCATGCCGAACTCAGAA $\mathrm{G})$ sequencing primers. The mutants of MnSOD-3WT were designated $\mathrm{H} 30 \mathrm{~N}$ and $\mathrm{H} 30 \mathrm{~F}$.

\section{Protein purification and characterization}

The synthesis of recombinant MnSOD was carried out in E. coli strain, OX326A ( $\Delta \operatorname{sodA}, \Delta \operatorname{sodB})$, kindly provided by Prof. Steinman, Albert Einstein College of Medicine, New York (Steinman 1992). Both the production and purification of the all the proteins used in this study were performed as previously described (Trinh et al. 2008). Concentrations of pure protein were measured by absorbance at $280 \mathrm{~nm}$ using the extinction coefficient of $43,340 \mathrm{M}^{-1} \mathrm{~cm}^{-1}$. The manganese and iron content of the purified protein was determined by GF-AAS or ICP-MS. Superoxide dismutase activity was measured spectrophotometrically as described by McCord and Fridovich and Ysebaert-Vanneste and Vanneste, whereby cytochrome $c$ serves as the detector and xanthine-xanthine oxidase as the superoxide generator (McCord and Fridovich 1969; Ysebaert-Vanneste and Vanneste 1980). The inhibition of MnSOD activity by the substrate analog, sodium azide, was measured by the cytochrome $c$ assay following $10 \mathrm{~min}$ incubation at room temperature with $4 \mathrm{mM}$ or $10 \mathrm{mM}$ sodium azide. Optical absorption spectra of MnSOD and H30N (3 mg mL $\mathrm{mL}^{-1}$ in $10 \mathrm{mM}$ Tris. $\mathrm{Cl} \mathrm{pH}$ 8.0) in the absence and presence of $100 \mathrm{mM}$ sodium azide were collected using a Beckman DU7500 diode array spectrophotometer.

\section{Crystallization, data collection, structure determination, and refinement}

The hanging-drop vapor diffusion method was used to grow crystals from drops composed of $2 \mu \mathrm{L}$ protein $(8 \mathrm{mg} /$ $\mathrm{mL}$ ) and $2 \mu \mathrm{L}$ reservoir solution equilibrated at $18^{\circ} \mathrm{C}$. The optimal reservoir solution $(500 \mu \mathrm{L})$ for $\mathrm{H} 30 \mathrm{~F}$ and $\mathrm{H} 30 \mathrm{~N}$ consisted of $0.1 \mathrm{M}$ bicine $\mathrm{pH} 9.0$ and $2.8 \mathrm{M}$ ammonium sulfate. Crystals grew to $350 \times 300 \times 300 \mu \mathrm{m}$ and were flashcooled in liquid nitrogen liquor after soaking for $30 \mathrm{~s}$ in solution mother liquor containing $25 \%$ glycerol as cryoprotectant solution before mounting on loops for data collection. X-ray diffraction data were recorded at $100 \mathrm{~K}$ on stations I02, and I04, respectively, at the Diamond Light Source Ltd using a Dextris Pilatus $6 \mathrm{M}-\mathrm{F}$ detector. Data were integrated at 1.6 and $1.52 \AA$ resolution, respectively, using the program XIA2. Data reduction and any following calculations were carried out using the CCP4 program suite (Collaborative Computational Project, Number 4, 1994). Both crystals had a space group of $\mathrm{P} 4{ }_{1} 2{ }_{1} 2$, with unit-cell parameters $a=b=81.5 \AA, c=138.7 \AA$ for $\mathrm{H} 30 \mathrm{~F}$ and $a=b=82.5 \AA, c=135.2 \AA$ for H30N. Two subunits per asymmetric unit are present in each protein structure, comprising all amino acids in the sequence.

The $\mathrm{H} 30 \mathrm{~F}$ and $\mathrm{H} 30 \mathrm{~N}$ protein structures were determined using the $293 \mathrm{~K}$ native MnSOD-3WT structure as the search model, by difference Fourier. Model building and refinement were performed using Coot (Emsley et al. 2010) and REFMAC5 (Vagin et al. 2004), respectively. Non-crystallographic symmetry averaging was not employed during refinement. TLS parameters (Winn et al. 2001) based on a single-group TLS model for each monomer were calculated using the TLS Motion Determination server (http://skuld.bmsc.washington.edu/ tlsmd/) and refined 
in REFMAC5 during the final stages of refinement. The final structures of $\mathrm{H} 30 \mathrm{~F}$ and $\mathrm{H} 30 \mathrm{~N}$ were refined to $R=18.8 \%$ and $\mathrm{R}$ free $=20.6 \%$, and $R=17.0 \%$ and $\mathrm{R}$ free $=21.9 \%$, respectively, at $100 \mathrm{~K}$.

\section{Circular dichroism spectroscopy}

Protein stability was assessed by $\mathrm{CD}$ measurements using a Chirascan $^{\mathrm{TM}}$ CD spectrometer (Applied Photophysics, Leatherhead, UK) equipped with a Peltier temperature 4-cell auto-changer cell holder. Far-UV (180-260 nm) CD spectra of the proteins $\left(0.3 \mathrm{mg} \mathrm{mL}^{-1}\right.$ in $10 \mathrm{mM}$ potassium phosphate buffer $\mathrm{pH}$ 7.8) were recorded in a cuvette of $0.1 \mathrm{~cm}$ path length with a $4.3 \mathrm{~nm}$ bandwidth. To calculate the unfolding transition temperature $\left(\mathrm{T}_{\mathrm{m}}\right)$, the proteins were heated from 5 to $90{ }^{\circ} \mathrm{C}$ with a $2{ }^{\circ} \mathrm{C}$ step size and $\pm 0.2{ }^{\circ} \mathrm{C}$ tolerance for the thermal scans. The collected data were corrected for solvent contributions due to the phosphate buffer. The signal at $222 \mathrm{~nm}$ at different temperatures was used to determine the melting temperature after normalization of the curves. The $C D$ curves were normalized using the equation $\mathrm{CD}_{\text {norm }}=\frac{C D(T)-F U(T)}{F F(T)-F U(T)}$, whereby the $\mathrm{CD}_{(\text {norm })}$ is the normalized $\mathrm{CD}$ curve and $\mathrm{FF}(\mathrm{T})$ and $\mathrm{FU}(\mathrm{T})$ are the asymptotes of the original CD curves at high and low asymptotes, respectively. Data were fitted to an asymmetric ( $5^{\text {th }}$ parameter) least squares fit.

\section{HFEPR spectroscopy}

High-field, continuous-wave electron paramagnetic resonance (HFEPR) spectroscopy was applied to determine the coordination center of MnSOD-3WT and the H30N mutant protein. The HFEPR spectrometer has been described in detail elsewhere (Un et al. 2001). Field calibration was based on a $\mathrm{Mn}$ (II)-doped $\mathrm{MgO}$ standard sample ( $g=2.000101)$ (Burghaus et al. 1993). The absolute error in field measurements was $1 \mathrm{G}(0.1 \mathrm{mT})$ or $0.0001 \mathrm{in} \mathrm{g}$. All spectra were obtained using $10 \mathrm{G}$ modulation under non-saturating conditions at $285 \mathrm{GHz}$ with $5 \mathrm{G}$ resolution at $23 \mathrm{~K}$. The temperature was chosen to maximize the signal arising from the $m_{s}=-1 / 21 / 2$ transition at $285 \mathrm{GHz}$ (Un et al. 2004). The quality of spectra could be reproduced reliably twelve times and double integrated for three separate experiments. Samples $(500 \mu \mathrm{L}$ at $200 \mu \mathrm{M})$ were mixed with $10 \mathrm{mM}$ sodium dithionite $(30 \mu \mathrm{L})$ to reduce the metal center to the $\mathrm{Mn}^{2+}$ state. The samples were subsequently washed twice with $20 \mathrm{mM}$ Tris. Cl pH 7.8 and $5 \mathrm{mM}$ EDTA followed by a final wash with $20 \mathrm{mM}$ Tris.Cl pH 7.8. $500 \mu \mathrm{l}$ of sample were loaded in the EPR tubes ( $2 \mathrm{ml}$ Nalgene plastic cryogenic tubes, immediately frozen in liquid nitrogen and sored at $-80{ }^{\circ} \mathrm{C}$ to prevent reoxidation.

\section{Molecular dynamics simulations}

MD simulations were performed by AMBER 16 (Case et al. 2005). The force field parameters for amino acid residues were ff14SB. Our parameters represented $\mathrm{Mn}$ and $\mathrm{Fe}$ in the $2^{+}$state using the 12-6-4 LJ-type non-bonded model AMBER force field (frcmod.ions234lm_1264_tip3p). The TIP3P water solvent model with a thickness of at least $10 \AA$ was used, and chlorine ions were added as counterions. The system, including an explicit solvent model, was simulated with a periodic boundary condition, and the particle mesh Ewald method was used to process long-range electrostatic interactions. A cut-off of $10 \AA$ was used for nonbonding interactions. The complements of the hydrogen atoms, not be observed by X-ray crystallographic analysis, were performed by the tleap module of AmberTools. First, the structural minimizations were conducted for the initial structures. The minimization was done in three steps. This involved the first two steps consisting of 5000 minimization steps with harmonic constraint on protein atoms coordinates (force constant of 500 and $10 \mathrm{kcal} / \mathrm{mol}^{*} \mathrm{~A}$, respectively) and a third step consisting of 10000 minimization steps with no constraints. After the minimizations, MD simulations of the protein were performed for $80 \mathrm{~ns}$ at a constant temperature $(300 \mathrm{~K})$ and constant pressure (1 bar), using Langevin dynamics algorithm, a time-step of $2 \mathrm{fs}$ and non-bonded cutoff of $8 \AA$. Analysis was carried out using VMD (Humphrey et al. 1996).

\section{Cell culture}

The human K562 chronic myeloid leukemia cell line, received through collaboration with the Erasmus Medical Center, Rotterdam, was originally acquired from ATCC (cell line no. ATCC ${ }^{\circledR}$ CCL-243 ${ }^{\mathrm{TM}}$ ). The cells were stored in liquid nitrogen, with a low passage number $(<10)$ and tested negative for Mycoplasma infection. K562 cells were cultured under normal conditions $\left(5 \% \mathrm{CO}_{2}\right)$ at $37{ }^{\circ} \mathrm{C}$ in RPMI 1640 medium supplemented with $10 \%$ fetal bovine serum (FBS) and 1\% Penicillin-Streptomycin solution (5000 units/ $\mathrm{mL}$ of penicillin and $5000 \mu \mathrm{g} / \mathrm{mL}$ of streptomycin).

\section{Cell viability}

K562 cells in serum-free RPMI media were plated at $5 \times 10^{3}$ or $3 \times 10^{3}$ cells/well in white opaque 96-well plates and incubated for $24 \mathrm{~h}$ at $37^{\circ} \mathrm{C}$ and $5 \% \mathrm{CO}_{2}$ in a humidified atmosphere before the addition of MnSOD protein (MnSOD-3WT, $\mathrm{H} 30 \mathrm{~N}$ or H30F). A control supplemented with only Tris.Cl ( $\mathrm{pH}$ 8.0) was prepared in parallel. The cells were incubated further for 24-, 48-, and 72-h intervals in the presence of increasing amounts of protein. Cell viability was monitored at the end of each interval by the CellTiter-Glo reagent that 
generates a luminescent signal that is proportional to the amount of ATP present. Luminescence was recorded using a Mithras LB 940 Multimode Microplate Reader (Berthold Technologies) at $0.5 \mathrm{~s}$ per well integration time. All measurements were done in triplicate for a minimum of three independent experiments. In a similar manner, cells were also treated with catalase to confirm that the observed effect was in fact due to the hydrogen peroxide product of the SOD reaction. The 96-well plates were seeded with 5,000 K562 cells per well in serum-starved RPMI medium and incubated for $24 \mathrm{~h}$. Cells were then treated with 10 or $20 \mu \mathrm{g}$ MnSOD$3 \mathrm{WT}, 10$ or $20 \mu \mathrm{g}$ MnSOD-3WT together with $1 \mu \mathrm{g}$ catalase (3 Units) and $1 \mu \mathrm{g}$ catalase alone. The plates were incubated for 24, 48, and $72 \mathrm{~h}$. Cytotoxicity was evaluated using the CellTiter-Glo ${ }^{\circledR}$ luminescent cell viability assay. Measurements were performed in triplicate.

\section{Determination of cell death by flow cytometry and fluorescence microscopy}

Apoptosis and necrosis were analyzed by fluorescence double staining with Annexin V/Propidium iodide (PI) (Vermes et al. 1995) using the Alexa Fluor ${ }^{\circledR} 488$ Annexin V/Dead cell Apoptosis Kit (Invitrogen). Approximately $1 \times 10^{6}$ cells under serum-starved conditions and supplemented with MnSOD-3WT for $48 \mathrm{~h}$, were collected, washed with PBS and resuspended in $100 \mu \mathrm{L} 1 \mathrm{X}$ Annexin-binding buffer. Untreated K562 cells served as the control. A positive control for apoptosis was prepared by treating cells with benzo $(a)$ pyrene $(20 \mu \mathrm{M})$ for $72 \mathrm{~h}$. The cells were stained with Alexa Fluor ${ }^{\circledR} 488$ Annexin V $(5 \mu \mathrm{L})$ and PI $(1 \mu \mathrm{L}$ of $100 \mu \mathrm{g} \mathrm{mL}^{-1}$ ) and incubated in the dark for $15 \mathrm{~min}$ at room temperature. Data were collected using a BD FACSCalibur ${ }^{\mathrm{TM}}$ flow cytometer (BD Biosciences, USA) and analyzed using the BD CellQuest ${ }^{\mathrm{TM}}$ Pro software. Gating of the cells was based on a cell-associated fluorescence of 10,000 events per sample. Excitation was carried out at $488 \mathrm{~nm}$ using an argon laser line. Fluorescence was measured in channel 1 (FL1-H), which detected Alexa Fluor ${ }^{\circledR} 488$ (Annexin V) and channel 3 (FL3-H), which detected PI fluorescence. All the measurements were repeated six times. Staining of K562 cells by Annexin V and PI was further confirmed by microscopy, at 200X magnification under a bright-field or fluorescence microscope (Nikon Eclipse Ti-S). Photographs were taken using NIS-Elements BR 3.22.07 software (Nikon Instruments Inc. USA).

\section{Caspase activity assay}

Activation of caspases $3 / 7,8$, and 9 in the MnSOD3 WT-treated K562 cells $\left(5 \times 10^{3} /\right.$ well $)$ was measured with the appropriate Caspase-Glo assay. Following incubation with MnSOD-3WT $(20 \mu \mathrm{g}, 0.56 \mu \mathrm{M})(24,48$, and $72 \mathrm{~h})$ in 96-well white opaque plates under serum-starved conditions, the cells were allowed to equilibrate for $30 \mathrm{~min}$ at room temperature. The respective Caspase-Glo reagent $(100 \mu \mathrm{L})$ was added to each well and the contents of the wells were mixed for $1 \mathrm{~min}$ at $300 \mathrm{rpm}$. The plates were then incubated at room temperature for $2 \mathrm{~h}$. The luminescence of each sample was measured using a Mithras LB 940 Multimode Microplate Reader at an integration time of $0.5 \mathrm{~s}$ per well. Each experiment was performed in triplicate.

\section{Statistics}

For mammalian cell culture experiments, data were expressed as the mean \pm SEM. The statistical analysis involved a comparison of the untreated control and the treated cells for each of the individually assayed caspase, hence the Student's $t$ test was applied to each pair of samples assayed. The data collected for the cell viability assays were assessed using the one-way ANOVA and Dunnett's tests were performed for post hoc multiple comparisons. In all cases, statistical significance was defined as $p<0.05(*)$, $p<0.01(* *)$, or $p<0.001(* * *)$. Statistical analysis was carried out using Graphpad Prism ${ }^{\circledR} 6.0$ software (USA).

\section{Results}

\section{The active site of $\mathrm{H} 30 \mathrm{~N}$ forms a hexa coordinate metal center}

Structural and biophysical analyses of the H30N protein support the presence of a hexa coordinate center in the active site of the mutant enzyme. The crystals belong to the space group $\mathrm{P} 4{ }_{1} 2{ }_{1} 2$, with unit-cell parameters of $a=b=82.5 \AA, c=135.2 \AA$ and structural data were determined at a resolution of $1.52 \AA$. The asymmetric unit consists of two subunits that are designated $\mathrm{A}$ and $\mathrm{C}$. The tetrameric structure, with its dimer of dimers quaternary assembly, is very similar to that of both the native C. elegans MnSOD and human MnSOD as are its $\alpha$-helical hairpin $\mathrm{N}$-domain and $\alpha / \beta \mathrm{C}$-domain (Trinh et al. 2008) (Fig. 1).

The data collection and refinement statistics for the $100 \mathrm{~K}$ $\mathrm{H} 30 \mathrm{~N}$ and $\mathrm{H} 30 \mathrm{~F}$ structures are presented in Table 1.

In the wild-type protein, the active site adopts the five coordinate trigonal bipyramidal configuration, common to other MnSODs (Trinh et al. 2008), and the ligands being His26, His74, Asp155, His159, and a water/hydroxyl molecule (W1). His30 forms part of the hydrogen-bonded network by interacting with Tyr34 via two water molecules (Tyr34OH-W2-W3-His30NE2; $2.66 \AA$, $2.88 \AA$, and $2.79 \AA$, respectively) and Tyr162 (2.7 $\AA$ ) from the other subunit of the biological dimer (Hunter et al. 2015) (Fig. 2a). 
Fig. 1 Structures of the manganese superoxide dismutases used in this study. Secondary structure cartoon representations are shown with the manganese ion as a purple sphere and the active-site water, $\mathrm{W} 1$, as a red sphere. Ligands to the metal are shown as sticks. a The overall fold of the H30N mutant (cyan) with N30 indicated. b Superimposition of H30N (cyan) with wild type (green). RMSD $0.204 \AA$ (2684 atoms). c $\mathrm{H} 30 \mathrm{~F}$ (magenta) is depicted as in a with F30 indicated. d Superimposition of H30F (magenta) with wild type (green). RMSD $0.241 \AA$ (2570 atoms) a
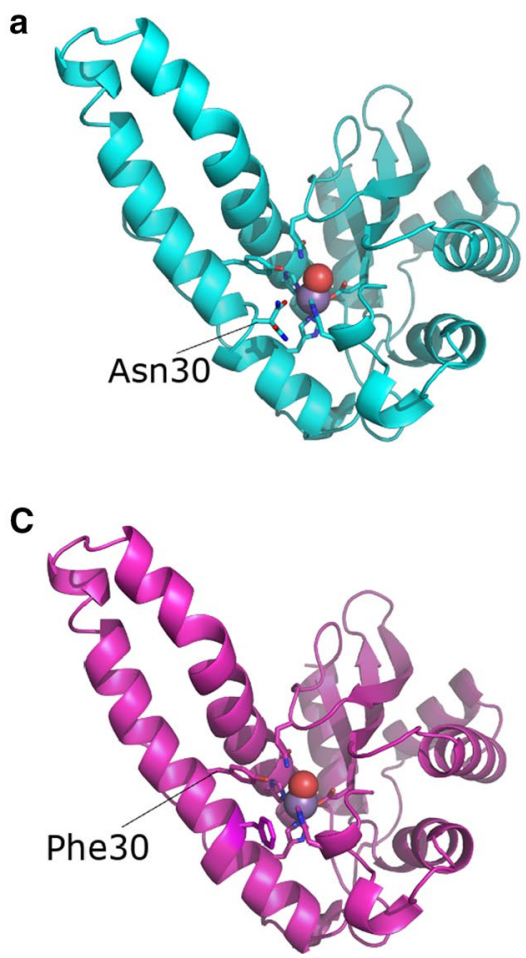

b

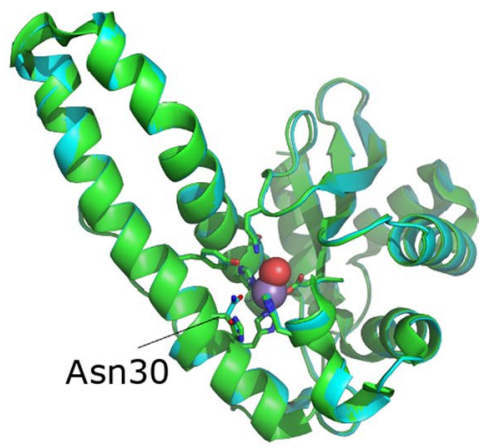

D

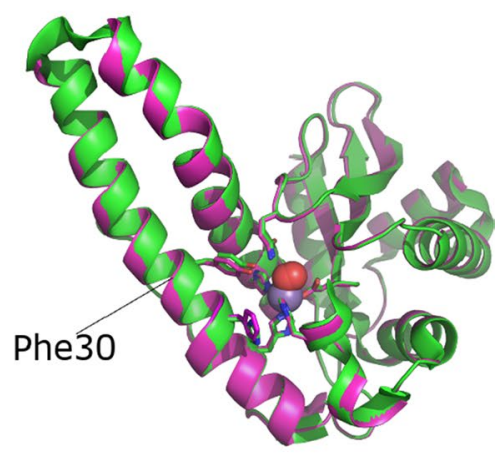

Analysis of the $\mathrm{H} 30 \mathrm{~N}$ active site shows no significant perturbation of the metal ligand interactions, specifically the interactions of His26, His74, His159, and Asp155 with the metal (Fig. 2b). Interestingly, the Asn30 residue can adopt two alternative rotameric positions (Fig. 2d). This was observed in the electron density of each of the active sites making up the asymmetric unit and in other lower resolution $\mathrm{H} 30 \mathrm{~N}$ crystal structures that we resolved. The designated Asn30 rotamer A is in a proximal conformation relative to the manganese center while rotamer $B$ is distal to the manganese (Fig. 2d). When in the proximal conformation, Asn30OD1 is $3.1 \AA$ away from the manganese center and is capable of acting as a sixth metal ligand. It is worth noting, however, that this distance between OD1 and $\mathrm{Mn}$ is a somewhat greater than the typical distance between the other metal ligand interactions taking place in the active site, which range between 2.0 and $2.2 \AA$. This may suggest a weaker interaction and would explain the presence of two alternate conformations for the Asn30 side chain. Otherwise, electron density would be expected for only the proximal conformation. In this position Asn30ND2 can also hydrogen bond directly with $\mathrm{Tyr} 34 \mathrm{OH}(3.3 \AA)$, with no intermediate water molecules. The narrow gap between these two residues at the mouth of the solvent funnel will undoubtedly hinder the flow of water and superoxide molecules to the active site, and may retard the release of the hydrogen peroxide product. The interaction between Asn30 and Tyr162 (from the neighboring subunit) is no longer feasible with rotamer A, at a distance of $6.4 \AA$ (Y162OH to N30ND2).
$\mathrm{ND} 2$ of the distal rotamer $\mathrm{B}$ is rotated $128.5^{\circ}$ away from rotamer A ND2, a movement that places it $5.7 \AA$ away from the manganese center and results in a five coordinate trigonal bipyramidal configuration of the active site as seen in wildtype enzymes. In position B, it is now capable of weakly hydrogen bonding with Tyr162 (3.4 $\mathrm{A}$ ) from the neighboring subunit. The distance between Asn30ND1 and Tyr34OH is similar to that between His 30ND1 and Tyr34OH in the native protein (5.7 $\AA$ and $5.5 \AA$, respectively). Surprisingly, an extensive, uninterrupted hydrogen-bonding network is observed between the distal Asn30 and the Tyr34, which would support the proton relay to the metal center. As opposed to what is observed in MnSOD-3WT, where two waters mediate bonding between Tyr34 and His30, no waters are observed between Tyr34 and Asn30 (Fig. 2a, b). It may be envisaged that the side chain of Asn30 is highly mobile due to the presence of two occupancies in the electron density, and that this may be caused by the attraction of Asn30 to the metal center. A decrease in enzyme activity, therefore, would result when the proximal rotamer obscures the active site and blocks substrate access to the metal. Replacement of the histidine by phenylalanine in $\mathrm{H} 30 \mathrm{~F}$ interrupts the hydrogen bond interaction that the His 30 normally makes with both Tyr162 and the solvent molecule network which bridges to Tyr34 (Fig. 2c). The Tyr34OH is displaced by $0.49 \AA$ in the direction of Phe 30 when compared to Tyr34OH in MnSOD-3WT and the gamma carbon (CG) of Phe30 is $1.39 \AA$ closer to Tyr $34 \mathrm{OH}$ than the CG side chain of His30 in MnSOD-3WT. This reduces the entrance 
Table 1 Crystallographic summary for the structures of $\mathrm{H} 30 \mathrm{~N}(100 \mathrm{~K})(\mathrm{pdb}: 6 \mathrm{~S} 0 \mathrm{D})$ and H30F (100 K) (pdb: 6QZM)

\begin{tabular}{|c|c|c|}
\hline & $\mathrm{H} 30 \mathrm{~N}$ & $\mathrm{H} 30 \mathrm{~F}$ \\
\hline Resolution range $(\AA)^{a}$ & $\begin{array}{l}58.32-1.52 \\
(1.56-1.52)\end{array}$ & $\begin{array}{l}40.74-1.60 \\
(1.64-1.60)\end{array}$ \\
\hline Space group & $P 4_{1} 2{ }_{1} 2$ & $P 4_{1} 2_{1} 2$ \\
\hline Unit-cell parameters $(\AA)$ & $\begin{array}{l}a=b=82.5 \\
c=135.2\end{array}$ & $a=b=81.49, c=138.66$ \\
\hline No. of observed reflections & $460,372(7104)$ & 59,113 \\
\hline No. of unique reflections & $66,925(3872)$ & 59,113 \\
\hline Data redundancy & $6.6(1.8)$ & 4.0 \\
\hline$<I / \sigma(I)>^{\mathrm{a}}$ & $1.4(1.5)$ & $4.0(1.5)$ \\
\hline Completeness $(\%)^{\mathrm{a}}$ & $96.5(71.4)$ & $100.0(100.0)$ \\
\hline$R_{\text {merge }}(\%)^{\mathrm{a}, \mathrm{b}}$ & $6.9(58.8)$ & $6.7(62.8)$ \\
\hline$R_{\text {pim }}(\%)$ & $3.6(57.7)$ & $1.9(17.3)$ \\
\hline$C C_{1 / 2}$ & $0.99(0.62)$ & $0.999(0.934)$ \\
\hline \multicolumn{3}{|l|}{ Refinement statistics } \\
\hline Resolution range for refinement $(\AA)$ & $58.32-1.52$ & $40.74-1.60$ \\
\hline$R$ factor $(\%)$ & 17.0 & 18.8 \\
\hline$R_{\text {free }}(\%)^{\mathrm{d}}$ & 21.9 & 20.6 \\
\hline No. of protein non-H atoms & 3131 & 3128 \\
\hline No. of water molecules & 295 & 369 \\
\hline No. of manganese ions & 2 & 2 \\
\hline No. of sulfate atoms & 7 & 3 \\
\hline R.m.s.d bond lengths $(\AA)^{\xi}$ & 0.010 & 0.012 \\
\hline R.m.s.d bond angles $\left({ }^{\circ}\right)^{\mathrm{c}}$ & 1.4 & 1.3 \\
\hline \multicolumn{3}{|c|}{$\begin{array}{l}\text { Ramachandran analysis, the percentage of resi- } \\
\text { dues in the regions of plot }(\%)^{\mathrm{e}}\end{array}$} \\
\hline Favored regions $\mathrm{e}^{\mathrm{e}}$ & 97.3 & 97.7 \\
\hline Outliers & 0 & 0 \\
\hline
\end{tabular}

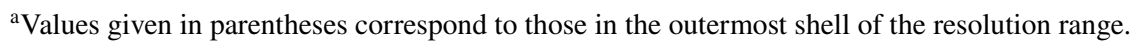

${ }^{\mathrm{b}} R_{\text {merge }}=\sum_{h k l} \sum_{i}\left|I_{i}(h k l)-\langle I(h k l)\rangle\right| / \sum_{h k l} \sum I_{i}(h k l)$.

${ }^{\mathrm{c}} R_{\text {pim }}=\sum_{h k l}\{1 /[N(h k l)-1]\}^{1 / 2} \sum_{i}\left|I_{i}(h k l)-\langle I(h k l)\rangle\right| / \sum_{h k l} \sum_{i} I_{i}(h k l)$.

${ }^{\mathrm{d}} R_{\text {free }}$ was calculated with $5 \%$ of the reflections set aside randomly.

${ }^{\mathrm{e}}$ Ramachandran analysis using the program MolProbity (Chen et al. 2010) to the solvent-filled funnel, which is located between residues Tyr34 and Phe30, by $1.5 \AA$ in H30F. Limited access to the superoxide substrate due to the steric effect of phenylalanine may explain the negligible activity exhibited by this particular protein.

Further characterization of $\mathrm{H} 30 \mathrm{~N}$ by $285 \mathrm{GHz}$ high-field electron paramagnetic resonance (HFEPR) confirmed the occurrence of a hexa coordinate center (Figs.3a and b). The HFEPR spectra of MnSOD-3WT resemble that of other MnSODs (Fig. 3a) (Un et al., 2004; Tabares et al. 2010)). The broad spectrum between 10.11 and $10.26 \mathrm{~T}$ arises from $m_{s}=-1 / 21 / 2$ spin transition of the Mn(II) center $(S=5 / 2)$. The fine structures arise from the hyperfine interaction of the ${ }^{55} \mathrm{Mn}(I=5 / 2)$ nucleus and six unpaired electrons. The shape and width are the consequence of the large $\mathrm{GHz} \mathrm{Mn}$ (II) zerofield interaction of the penta-coordinate $\mathrm{Mn}$ (II) center in SODs. This larger zero-field interaction is a characteristic of Mn(II)SODs and its specific magnitude highly correlates with the $\mathrm{Mn}$ or Fe metal specificity (Barwinska-Sendra et al. 2020). Upon addition of the azide, a narrower six-line component (from 10.13 to 10.20) was observed. As we have seen, (Tabares et al. 2006), this change corresponds to a large reduction of the zero-field interaction to about $1.4 \mathrm{GHz}$ as a consequence to the azide binding and is indicative of the formation of the hexa-coordinated center (Fig. 3b). As with other SODs, azide binding to MnSOD was only partial resulting in a mixture of azide-free penta-coordinated centers and azide-bound hexa-coordinated centers (Tabares et al. 2006). The HFEPR spectrum of $\mathrm{H} 30 \mathrm{~N}$ was similar to that of MnSOD-3WT with azide (Fig. 3a and b). This indicates the presence of penta- and hexa-coordinate centers in the resting state of the protein. We have shown that these hexa-coordinated centers can be obtained by water coordination to the $\mathrm{Mn}(\mathrm{II})$ center and observed an increase 

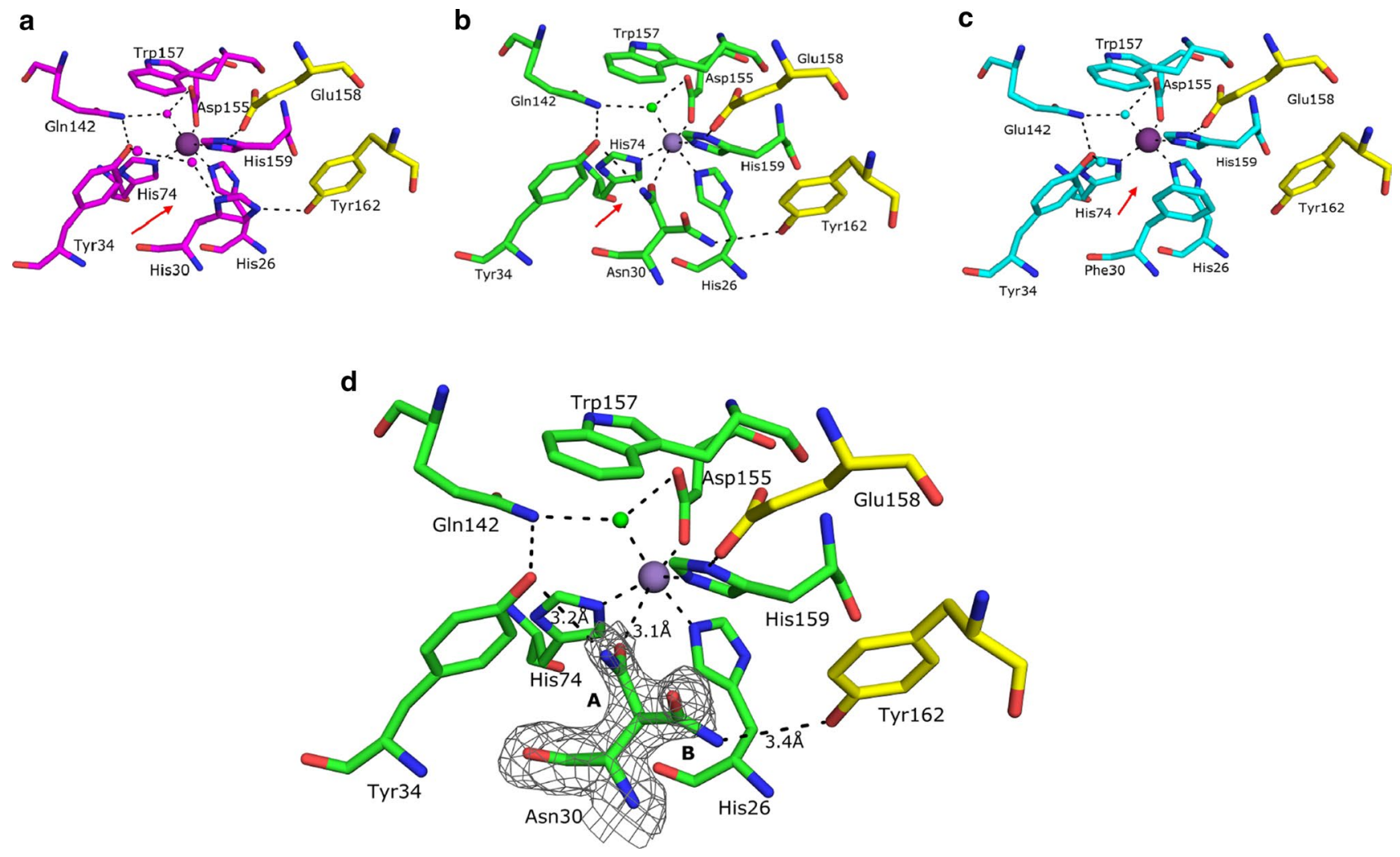

Fig. 2 Active sites of a MnSOD-3, b H30N, and c H30F, respectively, with $\mathrm{RMSD}=0.25$ and bonding according to the $\mathrm{H} 30 \mathrm{~N}$ active site. Amino acid residues and waters are depicted as magenta, green, and cyan for MnSOD-3, H30N, and H30F, respectively. The yellow residues labeled Glu158 and Tyr162 are from the other subunit of the biological dimer. The red arrows indicate the direction of the solvent in each active site d) Structure of the H30N active site. The hydro- gen-bonding network is illustrated as viewed from the approximate direction of substrate access. Both rotamers A and B of Asn30 are depicted, labeled, and surrounded by electron density $(\sigma$ level $=1)$. The manganese ion and the solvent molecules are shown as purple and green spheres, respectively. Bonding is illustrated by black dashes (pdb code: 6S0D) in water occupancy when in the Y34F mutant of E. coli MnSOD (Tabares et al. 2007). Therefore, the HFEPR spectra of H30N show that in the resting state the protein is in a composition of an approximately 1:1 mixture of normal penta-coordinate centers and water-bound hexa-coordinated centers. A much smaller six-line $\mathrm{Mn}$ (II) spectrum similar to that of non-specific $\left[\mathrm{Mn}\left(\mathrm{H}_{2} \mathrm{O}\right)_{6}\right]^{2+}$ was also detected. The concentration of species giving rise to the signal was estimated to be $<5 \%$ of the total Mn(II) concentration based on double integration analysis as we have shown previously) concentration based on double integration analysis as we have shown previously. Addition of azide showed negligible effect on the $\mathrm{H} 30 \mathrm{~N}$ spectrum (data not shown). The predominant oxidation state in MnSOD-3WT is Mn(III), which gives the characteristic peak at $480 \mathrm{~nm}$ in the visible absorbance spectrum (Fig. 4). The addition of $100 \mathrm{mM}$ azide to the protein caused a blue shift to $420 \mathrm{~nm}$ (Fig. 4). Azide is a substrate analog that binds to the manganese cofactor forming a hexa coordinate center (Hunter et al. 2015). The visible spectrum of $\mathrm{H} 30 \mathrm{~N}$ lacks the $480 \mathrm{~nm}$ peak, and yet it has a peak at $420 \mathrm{~nm}$ (Fig. 4).

Many of our protein purifications contained both iron and manganese in varying ratios and we never managed to isolate one over the other, even in minimal media. It, however, appears that the $\mathrm{H} 30 \mathrm{~N}$ mutant has a higher selectivity for iron than the wild type when prepared in minimal media. When prepared in 2TY media, the maximum manganese occupancy observed was 0.62 . When prepared in minimal media, $\mathrm{H} 30 \mathrm{~N}$ had an iron occupancy of 0.75 . In addition, the samples tend to be yellow in color and their visible spectrum is suggestive of iron. In contrast, the uptake of manganese by the MnSOD-3WT protein was $100 \%$. The protein used in the $\mathrm{H} 30 \mathrm{~N}$ crystal structures contained $0.7 \% \mathrm{Fe}$ and $0.3 \% \mathrm{Mn}$ when later analyzed. The metal of course cannot be determined from the X-ray structure which most likely is a hybrid in favor of iron. 


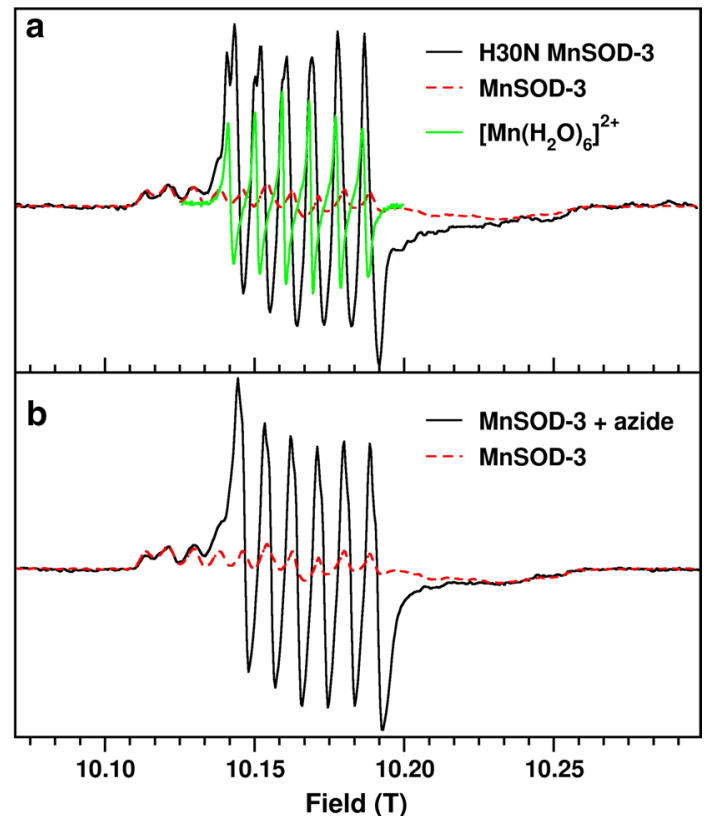

Fig. 3. $285 \mathrm{GHz}$ HFEPR spectra a $285 \mathrm{GHz}$ HFEPR spectra of MnSOD-3WT and H30N. The HFEPR spectrum of H30N (black) is superimposed on that of MnSOD-3WT (dashed red). The H30N spectrum is composed of three components, one similar to the MnSOD-3WT spectrum that corresponds to penta-coordinate $\mathrm{Mn}$ (II) centers and two six-lines component arising form hexacoordinated centers. One of these has the spectrum as that of $[\mathrm{Mn}(\mathrm{H} 2 \mathrm{O}) 6] 2+$. b The HFEPR spectra of MnSOD-3WT in the presence and absence of $50 \mathrm{mM}$ azide. The HFEPR spectrum of MnSOD-3WT after azide removal is depicted in red dotted lines

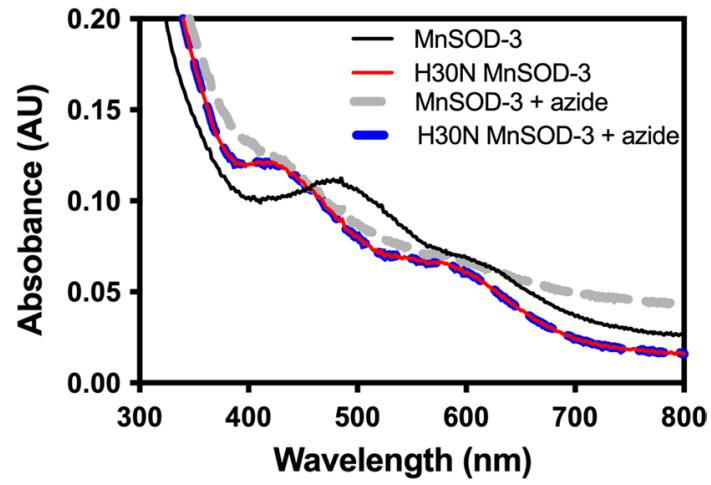

Fig. 4 Absorption spectra of oxidized MnSOD proteins in the absence and presence of $100 \mathrm{mM}$ azide. The characteristic Mn(III) peak at $478 \mathrm{~nm}$ is present in the visible absorption spectrum of MnSOD-3, while a maximum at $420 \mathrm{~nm}$ is observed for the $\mathrm{H} 30 \mathrm{~N}$ mutant

\section{Mutation of histidine 30 affects enzyme activity and stability}

As part of our study of SOD catalysis, we replaced the histidine with asparagine (Fig. 2). Analysis of H30N shows

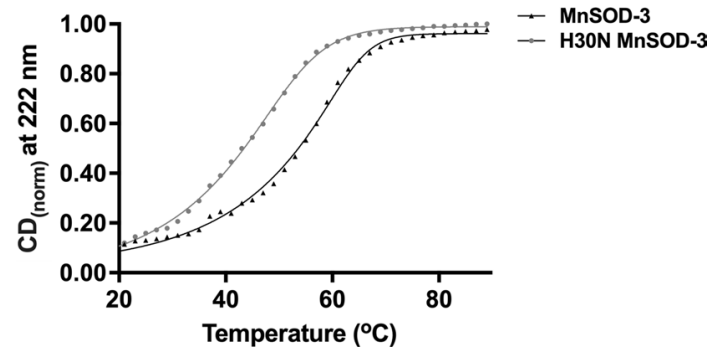

Fig. 5 Temperature stability normalized CD curves for MnSOD-3WT and $\mathrm{H} 30 \mathrm{~N}$ protein. The complete temperature unfolding profiles at $222 \mathrm{~nm}$ for MnSOD-3WT and H30N are depicted by an asymmetric (five parameter) least squares fit to calculate the melting temperature. The $T_{\mathrm{m}}$ of MnSOD and $\mathrm{H} 30 \mathrm{~N}$ were calculated to be 52 and $42{ }^{\circ} \mathrm{C}$, respectively

that at $25{ }^{\circ} \mathrm{C}$ the protein retains $22 \%$ the activity of the wild type (550 $\mathrm{U} \mathrm{mg}^{-1}$ vs $2500 \mathrm{U} \mathrm{mg}^{-1}$ ). The mutation also affects the conformational stability of the protein as the plot of the change in $\mathrm{CD}$ intensity at $222 \mathrm{~nm}$ with temperature (Fig. 5) shows a reduction of $10{ }^{\circ} \mathrm{C}$ in the midpoint of the unfolding transition or $\mathrm{T}_{\mathrm{m}}$ for $\mathrm{H} 30 \mathrm{~N}\left(52^{\circ} \mathrm{C}\right.$ MnSOD-3WT, $\left.42{ }^{\circ} \mathrm{C} \mathrm{H} 30 \mathrm{~N}\right)$. This instability is also reflected in a more pronounced loss of SOD activity both over time and with an increase in incubation temperature. Thermal inactivation assays whereby protein samples were incubated for $10 \mathrm{~min}$ at temperatures ranging from 25 to $85^{\circ} \mathrm{C}$ gave a $\mathrm{T}_{50}$ of $59{ }^{\circ} \mathrm{C}$ for MnSOD-3WT and $48{ }^{\circ} \mathrm{C}$ for $\mathrm{H} 30 \mathrm{~N}$. The reduced enzymatic activity of the $\mathrm{H} 30 \mathrm{~N}$ protein at room temperature may also be due to the movement of the Asn30 rotamer to a position where it blocks access of the superoxide substrate to the active site as observed in the resolved structure.

\section{Molecular dynamic simulations}

Molecular dynamics (MD) simulations of the H30N mutant protein were performed to obtain structural information where experimental techniques such as X-ray crystallography, are inapplicable. MD was conducted at $300 \mathrm{~K}$ as lower temperatures would artificially slow down the movement of the molecule. By performing MD simulations, we can get an indication of movement and subsequent interactions between the Asn30, other neighboring amino acids such as Tyr34 and inner-sphere waters and the metal cofactor which may not be visible in the X-ray structure of the molecule. The MD simulations that were carried out allowed the motion of the H30N protein to be simulated in defined conditions on the basis of classical molecular dynamics, using the structure including rotamer A of Asn30 as a starting point. As both manganese and iron ions were detected in the $\mathrm{H} 30 \mathrm{~N}$ protein by GF-AAS and ICP-MS, analysis, molecular dynamic simulations of the $\mathrm{H} 30 \mathrm{~N}$ mutant were performed using $\mathrm{Mn}$ and Fe parameters. Two simulations of $80 \mathrm{~ns}$ were performed to investigate the 


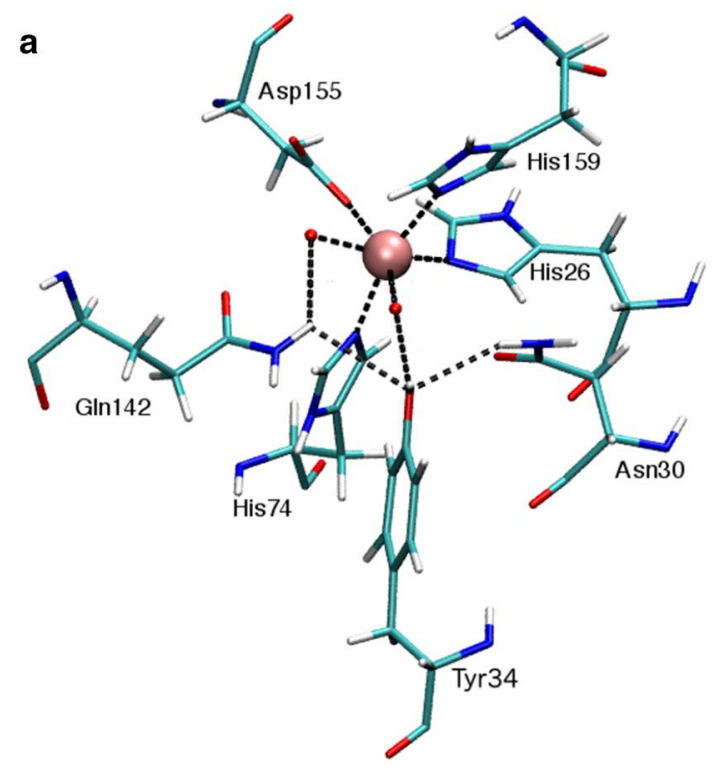

b

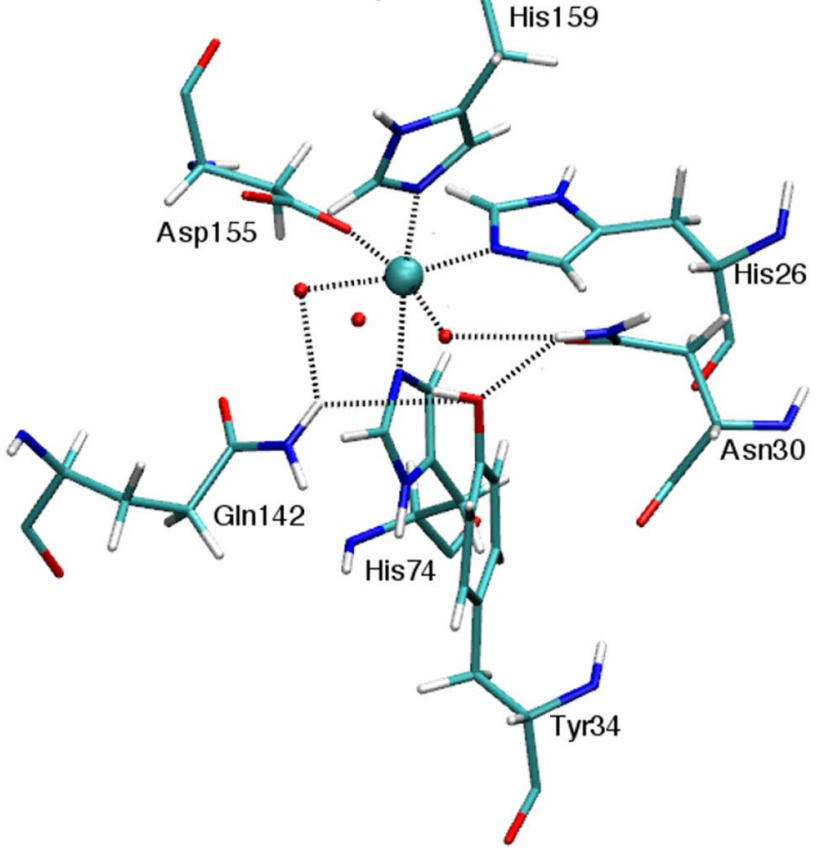

Fig. $6 \mathrm{H} 30 \mathrm{~N}$ active sites with a manganese and $\mathbf{b}$ iron cofactors observed from molecular dynamic simulations. These snapshots of the protein trajectory reveal the way in which the hydrogen-bonding network is maintained in the active sites containing either Mn or Fe. In $\mathbf{a}$, the hydrogen-bonding network was maintained for $18 \%$ of the simulation. In $\mathbf{b}$, the hydrogen-bonding network was maintained for $50 \%$ of the simulation. Red spheres indicate waters. Pink and cyan spheres indicate manganese and iron, respectively. Hydrogen bonding is illustrated as black dashes

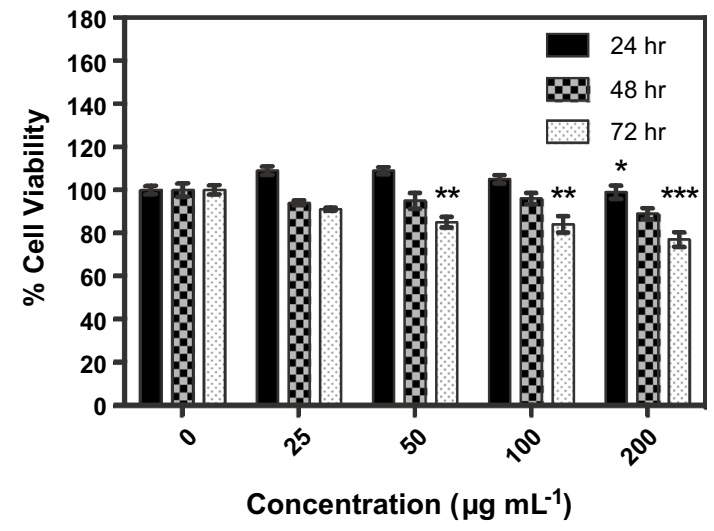

Fig. 7 Exogenous MnSOD-3WT treatment of K562 cells. Percentage cell viability of K562 cells as estimated by CellTiter Glo proliferation assay in 96-well plates with serum-free media, following 24,48 , and $72 \mathrm{~h}$ exposure to varying amounts of MnSOD-3WT. Results represent mean \pm SEM, $n=3$. Statistical significance was defined as $p<0.05(*)$ or $p<0.01(* *)$

effect of the mutation and any changes that may be due to the manganese or iron metal cofactor.

The presence of a well-connected hydrogen-bonding network that spans from the manganese, water, Gln142, Tyr34, and Asn30, was observed in only $18 \%$ of the frames in the simulation trajectory when $\mathrm{H} 30 \mathrm{~N}$ had manganese as its cofactor (Fig. 6a). On the other hand, the network of hydrogen bonding was observed in $50 \%$ of the frames constituting the simulation trajectory of the $\mathrm{H} 30 \mathrm{~N}$, which contained iron as its cofactor (Fig. 6b). In this case the network extended from the iron cofactor, moving to water, Gln142, Tyr34, Asn30, water, and ending back with iron. In contrast, no mediating waters were observed in the crystal structure determined for $\mathrm{H} 30 \mathrm{~N}$, apart from the water molecule coordinated to the metal cofactor. MD indicates that a change in the metal cofactor of the protein could actually alter the motions of the active-site residues and water molecules such that the hydrogen-bonding network could be maintained more regularly in the $\mathrm{H} 30 \mathrm{~N}$ simulation containing iron.

\section{Exogenous MnSOD and H3ON have opposing effects on the cell viability of K562 cells}

The K562 cells were seeded at $5 \times 10^{3} /$ well in serum-free RPMI $(100 \mu \mathrm{L})$ with increasing amounts of MnSOD-3WT and $\mathrm{H} 30 \mathrm{~N}$ to investigate the effect these SODs may have on the cell viability. Incubation of the cells with varying amounts of MnSOD-3WT for 24, 48 and $72 \mathrm{~h}$ showed a statistically significant decrease in viability in both a timedependent and a dose-dependent manner when compared to the untreated cells (Fig. 7). Incubation for $72 \mathrm{~h}$ in the presence of $50 \mu \mathrm{g} \mathrm{ml}^{-1}$ of MnSOD caused a $15 \%$ loss in viability. This effect was dose-dependent and was more pronounced 
at higher protein concentrations, exhibiting a 33\% decrease with $200 \mu \mathrm{g} \mathrm{ml}^{-1}$ of the protein. The latter parallels the loss in viability caused by incubation with $10 \mu \mathrm{M} \mathrm{H}_{2} \mathrm{O}_{2}$. To ensure that the observed effect was not just a consequence of osmotic stress due to the supplemented protein, a parallel experiment was performed with the relatively inactive $\mathrm{H} 30 \mathrm{~F}$ mutant. At the given concentrations, the H30F protein had no effect on the cell viability thereby supporting that the loss of viability observed for MnSOD-3WT was related to its superoxide dismutase activity (S1). The addition of only Tris.Cl buffer also had no effect on cell growth (S2). The effect of catalase on the cell viability was also examined. Treatment of K562 cells with $30 \mathrm{U}$ catalase improved cellular viability by $65 \%$ after $48 \mathrm{~h}$ of incubation. This indicates that hydrogen peroxide is present in serum-free media, in amounts that curtail proliferation, demonstrating that the removal of hydrogen peroxide by catalase does suppress apoptosis in the MnSOD-treated cells (Halliwell et al. 2000).

When we treated the K562 cells with H30N we were surprised to observe an increase in cell viability. The greatest increase of $282 \%( \pm 2.61), 272 \%( \pm 1.96)$, and $285 \%$ $( \pm 3.75)$ occurred after $48 \mathrm{~h}$ when cells were supplemented with $25 \mu \mathrm{g} \mathrm{ml}^{-1}, 50 \mu \mathrm{g} \mathrm{ml}^{-1}$, and $100 \mu \mathrm{g} \mathrm{ml}^{-1}$ of the protein, respectively (Fig. 8). Untreated cells or cells treated exogenously with $\mathrm{H} 30 \mathrm{~F}$ or Tris. $\mathrm{Cl}$ exhibited no significant changes. After $72 \mathrm{~h}$, cells showed a decrease in viability that may be attributed to a depletion of nutrients and optimal growth conditions (results not shown).

\section{Exogenous MnSOD triggers apoptosis in K562 cells}

Using the 48-h sample of MnSOD-3WT-treated cells, we tested whether the observed loss of viability was related to

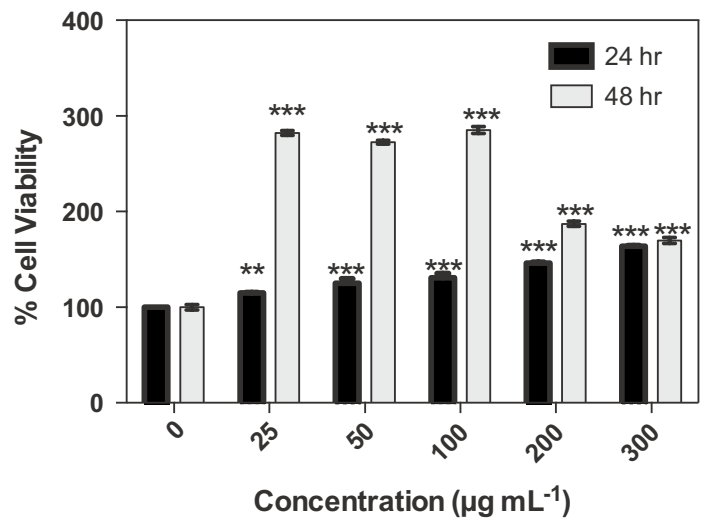

Fig. 8 Effects of the H30N on K562 cell proliferation by CellTiter$\mathrm{Glo}^{\circledR}$ test. Various concentrations of $\mathrm{H} 30 \mathrm{~N}$ were added to the medium and incubated for 24 and $48 \mathrm{~h}$, respectively. Any measurements taken after $72 \mathrm{~h}$ incubation resulted in substantial cell death due to previous cell overgrowth. Data were presented as means \pm SEM, $n=3$. Statistical significance was defined as $p<0.01(* *)$ or $p<0.001(* * *)$ apoptosis or necrosis. The fluorophore-conjugated Annexin V identifies apoptotic cells by binding to phosphatidylserine that moves from the inner to the outer leaflet of the plasma membrane in apoptotic cells. Necrotic cells, on the other hand, are permeable to propidium iodide (PI) that binds to nuclear material and stains the cells red thereby distinguishing necrotic cells from both viable and apoptotic cells. Unstained viable K562 cells were used as a negative control (Fig. 9a). PI stained K562 cells were used as a positive control for necrosis (Fig. 9b). Benzo(a)pyrene-induced apoptotic cells served as the positive control to define gating and quadrant parameters for flow cytometry. The populations of cells that were observed following MnSOD-3WT treatment included cells that were viable and not undergoing apoptosis in the lower left of quadrant (Annexin V and PI negative, Fig. 9c); cells undergoing early apoptosis, observed in the lower right of the quadrant (Annexin $\mathrm{V}$ positive and PI negative, Fig. 9d); cells in a late stage of apoptosis observed in the upper right quadrant (Annexin $\mathrm{V}$ positive and PI positive) and dead cells observed in the upper left corner (Annexin negative and PI positive). The percentage of cells in the late apoptotic and necrotic stage was $6 \%$ higher in the treated K562 cells compared to the untreated cells while the viability of the treated cells was decreased by $12 \%$, with respect to the untreated control. These results were statistically significant and compared well with the loss in cell viability measured by the CellTiter-Glo ${ }^{\circledR}$ assay (Fig. 7). Progression of apoptosis was also confirmed by bright field and fluorescence microscopy (Fig. 10), following Annexin V/PI double staining of the treated cells. The bright-field images show the healthy Annexin V and PI negative cells. The cells in early apoptotic stages stained only green due to Annexin $\mathrm{V}$, while the necrotic cells were stained only red by PI. The late apoptotic cells appear stained by both Annexin V and PI (green and red). The larger number of cells in a late apoptotic stage in treated cells suggests a greater induction of apoptosis due to MnSOD-3WT treatment.

\section{MnSOD-3WT treatment causes differential caspase activation}

We investigated the activation of caspases $3 / 7,8$, and 9 to further confirm that the observed loss in cell viability was in fact due to the onset of apoptosis. Significant increases in caspase $3 / 7,8$, and 9 activities were recorded after $72 \mathrm{~h}$ of MnSOD$3 \mathrm{WT}$ treatment (Fig. 11). Relative to the untreated samples, the greatest increase was recorded for the initiators of apoptosis, caspase-9 (88\%) and caspase-8 (71\%) and to a lesser extent, the executors of apoptosis caspase 3 and 7 (31\%). Our results, therefore, suggest that the hydrogen peroxide product of the exogenous SOD reaction stimulates both the extrinsic (via surface death receptor) and the intrinsic (via mitochondria) apoptotic pathways (Siegel et al. 2003). Both extrinsic and 
Fig. 9 Analysis of apoptosis and necrosis in MnSOD-3WTtreated K562 cells using flow cytometry. a Unstained viable K562 cells, acting as a negative control. b PI stained necrotic K562 cells, acting as a positive control. c Untreated K562 cells double stained with Annexin $\mathrm{V}$ and PI $(n=6)$. d MnSOD$3 \mathrm{WT}$ treated $\left(200 \mu \mathrm{g} \mathrm{mL}^{-1}\right)$ K562 cells double stained with Annexin V and PI $(n=4)$.
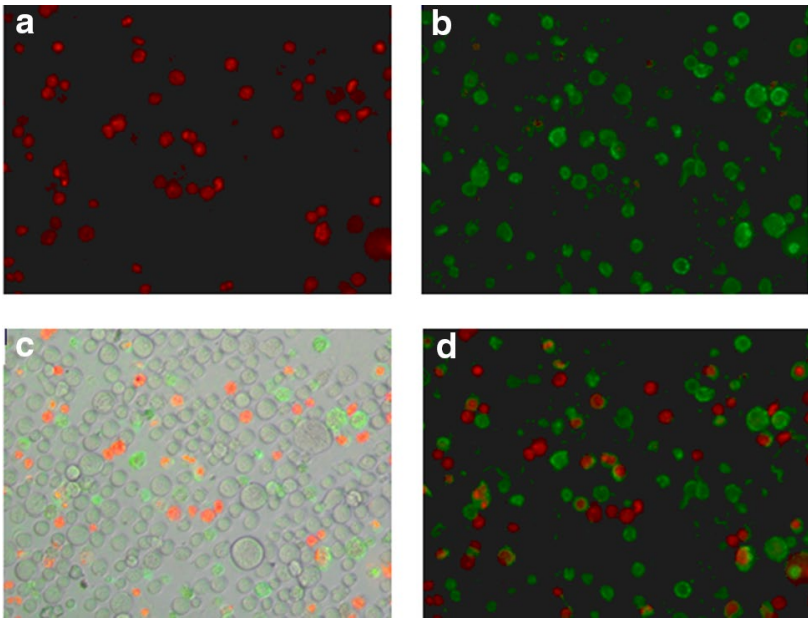

Fig. 10 Apoptosis assessment of MnSOD-3WT-treated K562 cells by representative bright-field and fluorescence microscopy images (×200). a Necrotic cells stained by PI only (red). b Apoptotic cells stained by Annexin V only (green). c Bright-field image illustrating Annexin V/PI stained cells. d Merged fluorescence image illustrating Annexin V/PI stained cells

intrinsic pathways converge to activate caspases 3 and 7 that in turn, transmit downstream signals for cell-wide disassembly.
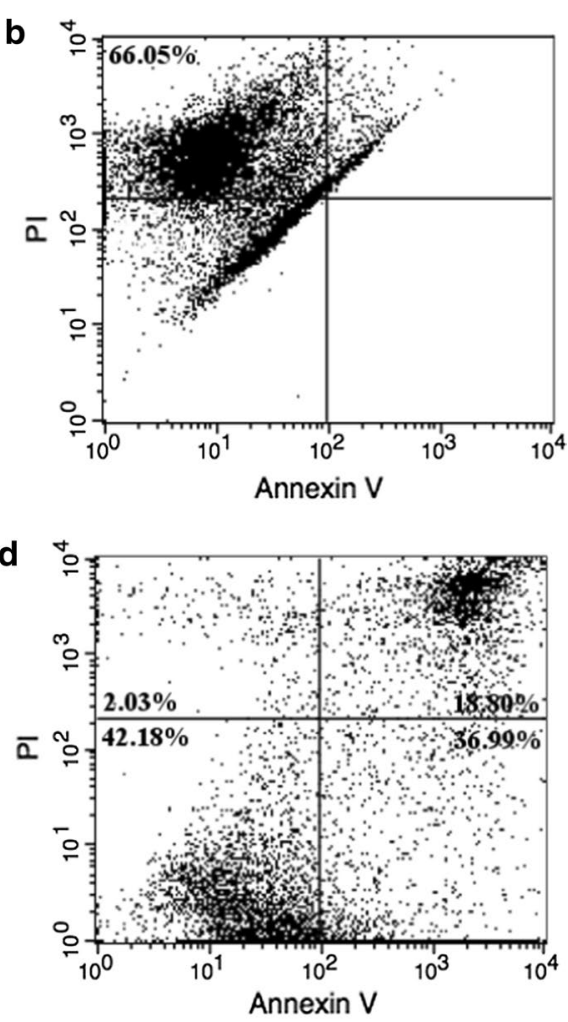
MnSOD-3WT can exert on the proliferation of K562 cells when added exogenously.

One of the main changes induced by the single-amino acid substitution of histidine by asparagine was a reduction in the incorporation of manganese in the active site and an increase in that of iron. Such an occurrence was also observed in the Q142H mutant of C. elegans MnSOD, whereby substitution of the active-site residue at position 142 from glutamine to histidine also changed the metal selectivity from manganese to iron (Hunter et al. 2018). Preliminary results also revealed that metal selectivity is altered in the $\mathrm{H} 30 \mathrm{~N}$ mutant of human MnSOD (unpublished). However, it was observed that when histidine replaced glutamine 142 in the active site, the enzyme retained $50 \%$ of its activity and became cambialistic for its metal cofactor exhibiting very similar specific activity with either manganese or iron. Although the H30N mutant protein also revealed the spontaneous uptake of $\mathrm{Fe}$ in addition to Mn, enzyme activity was drastically reduced to $22 \%$ in this case. The decrease in enzyme activity of H30N was also accompanied by a decrease in the thermal melting temperature $\left(42^{\circ} \mathrm{C}\right)$ when compared to MnSOD-3WT $\left(52^{\circ} \mathrm{C}\right)$. The loss of the interaction between the Asn30 and Tyr 162 from the neighboring subunit) may be a contributing factor to the loss of conformational stability observed by CD and thermal inactivation of enzyme function.

Spectrophotometric, HFEPR, and X-ray crystallography experiments together with MD simulations of $\mathrm{H} 30 \mathrm{~N}$ with an iron cofactor all consolidate the fact that MnSOD$3 \mathrm{WT}$ undergoes a change in its active-site geometry upon the single mutation from histidine to asparagine at position 30. HFEPR experiments especially highlight the presence of mixed geometry active sites, as the spectrum for the H30N mutant shows the fingerprint feature of typical penta-coordinate manganese center, as well as the six-line spectral feature, which represents octahedral geometries. The absence of a $480 \mathrm{~nm}$ peak in the absorption spectrum of $\mathrm{H} 30 \mathrm{~N}$ also indicates the minimal presence of manganese in the protein, when compared to its wild-type counter-part. The solved X-ray structure and the MD simulation demonstrate the increased mobility that asparagine replacement has brought about in the second sphere of the $\mathrm{H} 30 \mathrm{~N}$ protein, in order for the protein to maintain a level of functional catalysis. The X-ray structure demonstrates the adoption of two rotamers by Asn30, one of which can directly coordinate with the cofactor to form octahedral active-site geometry. In the X-ray structure, Asn30OD1 proximal position forms the sixth coordination with the manganese. However, in the MD simulation in Fig. 6a the Asn30OD1 is facilitating the sixth coordination via a water molecule to the manganese cofactor. The MD simulation of $\mathrm{H} 30 \mathrm{~N}$ containing iron as a cofactor also illustrates how Asn30 facilitates the formation of octahedral centers by coordinating with the metal cofactor via an intermediary water molecule.
Although MnSOD protein cannot enter the cell, the hydrogen peroxide product of its reaction is capable of crossing the plasma membrane by diffusion and via aquaporins (Vieceli Dalla Sega et al. 2014). The K562 cells were selected for this study because they are non-adherent cells that produce high levels of superoxide radicals extracellularly, via the activity of their over-expressed membranebound NADPH oxidase (de Mendez and Leto 1995). This superoxide may, in turn, serve as substrate for the exogenously supplemented superoxide dismutase.

The drastic changes in active-site geometry in the $\mathrm{H} 30 \mathrm{~N}$ mutant have also resounded in the observed effect on K562 cells, upon exogenous addition of this protein. One inference that may be derived from the modified active-site structure and activity of $\mathrm{H} 30 \mathrm{~N}$ together with the signaling properties of hydrogen peroxide would be that $\mathrm{H} 30 \mathrm{~N}$ has a catalytic mechanism, which generates hydrogen peroxide product at a level, which stimulates cell growth. Davis et al., in fact state that hydrogen peroxide can act as a secondary messenger with the unique effects of stimulating cell proliferation at concentrations of $100 \mathrm{nM}$ to $1 \mu \mathrm{M}$ (Davis et al. 2004). On the other hand, C. elegans MnSOD, is catalytically similar to human H30N (Hunter et al. 2015), as both exhibit a low level of product inhibition. Therefore, both of these enzymes may produce larger amounts of hydrogen peroxide, which result in the anti-proliferative effects observed on K562 cells (Davis et al. 2004). While the presence of MnSOD-3WT caused a dose-dependent decrease in proliferation, interestingly, the presence of both MnSOD-3WT and catalase resulted in a $17 \%$ increase in cell proliferation. This highlights the fine balance between hydrogen peroxide-induced proliferation and apoptosis in cellular systems. This was further substantiated by the comparison of the cellular viability in response to SODs with varying activities. This ties in with the apoptosis-inducing character of hydrogen peroxide that is the product of the SOD reaction. The highly active MnSOD-3WT caused a decrease in viability by triggering apoptosis. The $\mathrm{H} 30 \mathrm{~N}$ protein that has a fifth of the activity of the wild type stimulated cellular proliferation, to an extent similar to that exhibited by the combination of MnSOD-3WT and catalase. The fact that no change in viability resulted from treatment with the inactive $\mathrm{H} 30 \mathrm{~F}$ protein suggests that the level of hydrogen peroxide produced by MnSOD actually influences the cellular switch between proliferation and apoptosis.

Supplementary Information The online version contains supplementary material available at https://doi.org/10.1007/s00249-021-01544-2.

Acknowledgements This work was supported by the Dean's award vote Medin08-01, the COST Actions (CM1305, CM1306, CA15126), STSM reference number: 38437 awarded by COST Action CM1305 to RB. The French Embassy to Malta, the CNRS and MCST awarded 
two scholarships to RB for the HFEPR experiments at CEA, Saclay. The Chirascan spectrophotometer was funded by the Wellcome Trust, grant code 094232 awarded to Prof Sheena Radford. This work was also supported by the biophysics platform of the Institute for Integrative Biology of the Cell supported by French Infrastructure for Integrated Structural Biology (FRISBI) ANR-10-INBS-05-05.

Open Access This article is licensed under a Creative Commons Attribution 4.0 International License, which permits use, sharing, adaptation, distribution and reproduction in any medium or format, as long as you give appropriate credit to the original author(s) and the source, provide a link to the Creative Commons licence, and indicate if changes were made. The images or other third party material in this article are included in the article's Creative Commons licence, unless indicated otherwise in a credit line to the material. If material is not included in the article's Creative Commons licence and your intended use is not permitted by statutory regulation or exceeds the permitted use, you will need to obtain permission directly from the copyright holder. To view a copy of this licence, visit http://creativecommons.org/licenses/by/4.0/.

\section{References}

Abreu IA, Cabelli DE (2010) Superoxide dismutases-a review of the metal-associated mechanistic variations. Biochim Biophys Acta 1804:263-274. https://doi.org/10.1016/j.bbapap.2009.11.005

Barwinska-Sendra A, Garcia YM, Sendra KM et al (2020) An evolutionary path to altered cofactor specificity in a metalloenzyme. Nat Commun 11:2738. https://doi.org/10.1038/s41467-020-16478-0

Bie AS, Fernandez-Guerra P, Birkler RI et al (2016) Effects of a Mutation in the HSPE1 gene encoding the mitochondrial co-chaperonin HSP10 and its potential association with a neurological and developmental disorder. Front Mol Biosci 3:65. https://doi.org/10.3389/ fmolb.2016.00065

Bull C, Niederhoffer EC, Yoshida T, Fee JA (1991) Kinetic studies of superoxide dismutases: properties of the manganese-containing protein from Thermus thermophilus. J Am Chem Soc 113:40694076. https://doi.org/10.1021/ja00011a003

Burghaus O, Plato M, Rohrer M, Moebius K, MacMillan F, Lubitz W (1993) 3-mm High-field EPR on semiquinone radical anions Q.cntdot.- related to photosynthesis and on the primary donor P.cntdot.+ and acceptor QA.cntdot.- in reaction centers of Rhodobacter sphaeroides R-26. J Phys Chem 97:7639-7647. https:// doi.org/10.1021/j100131a037

Case DA, Cheatham TE, Darden T et al (2005) The Amber biomolecular simulation programs. J Comput Chem 26:1668-1688. https:// doi.org/10.1002/jcc. 20290

Chen VB, Arendall WB, Headd JJ, Keedy DA, Immormino RM, Kapral GJ, Murray LW, Richardson JS, Richardson DC (2010) MolProbity: all-atom structure validation for macromolecular crystallography. Acta Crystallogr A D66:12-21

Connor KM, Hempel N, Nelson KK et al (2007) Manganese superoxide dismutase enhances the invasive and migratory activity of tumor cells. Cancer Res 67:10260-10267. https://doi.org/10.1158/00085472.CAN-07-1204

Davis CA, Hearn AS, Fletcher B et al (2004) Potent anti-tumor effects of an active site mutant of human manganese-superoxide dismutase Evolutionary conservation of product inhibition. J Biol Chem 279:12769-12776. https://doi.org/10.1074/jbc.M3106 23200

de Mendez I, Leto TL (1995) Functional reconstitution of the phagocyte NADPH oxidase by transfection of its multiple components in a heterologous system. Blood 85:1104-1110
Dhar SK, St Clair DK (2012) Manganese superoxide dismutase regulation and cancer. Free Radic Biol Med 52:2209-2222. https://doi. org/10.1016/j.freeradbiomed.2012.03.009

Dhar SK, Tangpong J, Chaiswing L, Oberley TD, St Clair DK (2011) Manganese superoxide dismutase is a p53-regulated gene that switches cancers between early and advanced stages. Cancer Res 71:6684-6695. https://doi.org/10.1158/0008-5472.CAN-11-1233

Emsley P, Lohkamp B, Scott WG, Cowtan K (2010) Features and development of Coot. Acta Crystallogr D Biol Crystallogr 66:486-501. https://doi.org/10.1107/S0907444910007493

Halliwell B, Clement MV, Ramalingam J, Long LH (2000) Hydrogen peroxide. Ubiquitous in cell culture and in vivo? IUBMB Life 50:251-257. https://doi.org/10.1080/713803727

Han D, Antunes F, Canali R, Rettori D, Cadenas E (2003) Voltagedependent anion channels control the release of the superoxide anion from mitochondria to cytosol. J Biol Chem 278:5557-5563. https://doi.org/10.1074/jbc.M210269200

Hearn AS, Tu C, Nick HS, Silverman DN (1999) Characterization of the product-inhibited complex in catalysis by human manganese superoxide dismutase. J Biol Chem 274:24457-24460. https://doi. org/10.1074/jbc.274.35.24457

Honda Y, Honda S (1999) The daf-2 gene network for longevity regulates oxidative stress resistance and $\mathrm{Mn}$-superoxide dismutase gene expression in Caenorhabditis elegans. FASEB J 13:1385-1393

Hsu JL, Hsieh Y, Tu C, O’Connor D, Nick HS, Silverman DN (1996) Catalytic properties of human manganese superoxide dismutase. J Biol Chem 271:17687-17691. https://doi.org/10.1074/jbc.271. 30.17687

Humphrey W, Dalke A, Schulten K (1996) VMD: visual molecular dynamics. J Mol Graph 14(33-38):27-38. https://doi.org/10.1016/ 0263-7855(96)00018-5

Hunter GJH, Hunter T (2013) GroESL protects superoxide dismutase (SOD) - Deficient cells against oxidative stress and is a chaperone for SOD. Health 5:1719-1729. https://doi.org/10.4236/health. 2013.510232

Hunter T, Bannister WH, Hunter GJ (1997) Cloning, expression, and characterization of two manganese superoxide dismutases from Caenorhabditis elegans. J Biol Chem 272:28652-28659. https:// doi.org/10.1074/jbc.272.45.28652

Hunter GJ, Trinh CH, Bonetta R, Stewart EE, Cabelli DE, Hunter T (2015) The structure of the Caenorhabditis elegans manganese superoxide dismutase MnSOD-3-azide complex. Protein Sci 24:1777-1788. https://doi.org/10.1002/pro.2768

Hunter T, Bonetta R, Sacco A, Sultana PM, Trinh C, Hunter GJ et al (2018) A single mutation is sufficient to modify the metal selectivity and specificity of a eukaryotic manganese superoxide dismutase to encompass iron. Chemistry 24:5303-5308. https://doi. org/10.1002/chem.201704655

Magnoni R, Palmfeldt J, Hansen J, Christensen JH, Corydon TJ, Bross P (2014) The Hsp60 folding machinery is crucial for manganese superoxide dismutase folding and function. Free Radic Res 48:168-179. https://doi.org/10.3109/10715762.2013.858147

McAdam ME, Fox RA, Lavelle F, Fielden EM (1977) A pulse-radiolysis study of the manganese-containing superoxide dismutase from Bacillus stearothermophilus. A kinetic model for the enzyme action. Biochem J 165:71-79. https://doi.org/10.1042/bj1650071

McCord JM, Fridovich I (1969) Superoxide dismutase. An enzymic function for erythrocuprein (hemocuprein). J Biol Chem 244:6049-6055

Sheng Y, Butler Gralla E, Schumacher M, Cascio D, Cabelli DE, Valentine JS (2012) Six-coordinate manganese(3+) in catalysis by yeast manganese superoxide dismutase. Proc Natl Acad Sci USA 109:14314-14319. https://doi.org/10.1073/pnas.1212367109

Sheng Y, Abreu IA, Cabelli DE, Maroney MJ, Miller AF, Teixeira M, Valentine JS (2014) Superoxide dismutases and superoxide 
reductases. Chem Rev 114:3854-3918. https://doi.org/10.1021/ cr4005296

Siegel RM, Muppidi J, Roberts M, Porter M, Wu Z (2003) Death receptor signaling and autoimmunity. Immunol Res 27:499-512. https://doi.org/10.1385/IR:27:2-3:499

Steinman HM (1992) Construction of an Escherichia coli K-12 strain deleted for manganese and iron superoxide dismutase genes and its use in cloning the iron superoxide dismutase gene of Legionella pneumophila. Mol Gen Genet 232:427-430. https:// doi.org/10.1007/bf00266247

Tabares LC, Cortez N, Hiraoka BY, Yamakura F, Un S (2006) Effects of substrate analogues and $\mathrm{pH}$ on manganese superoxide dismutases. Biochemistry 45:1919-1929. https://doi.org/10.1021/ bi051947m

Tabares LC, Cortez N, Un S (2007) Role of tyrosine-34 in the anion binding equilibria in manganese(II) superoxide dismutases. Biochemistry 46:9320-9327. https://doi.org/10.1021/bi700438j

Tabares LC, Gatjens J, Un S (2010) Understanding the influence of the protein environment on the Mn(II) centers in Superoxide Dismutases using High-Field Electron Paramagnetic Resonance. Biochim Biophys Acta 1804:308-317. https://doi.org/10.1016/j. bbapap.2009.09.027

Trinh CH, Hunter T, Stewart EE, Phillips SE, Hunter GJ (2008) Purification, crystallization and X-ray structures of the two manganese superoxide dismutases from Caenorhabditis elegans. Acta Crystallogr Sect F Struct Biol Cryst Commun 64:1110-1114. https:// doi.org/10.1107/S1744309108037056

Un S, Dorlet P, Voyard G, Tabares LC, Cortez N (2001) High-field EPR characterization of manganese reconstituted superoxide dismutase from Rhodobacter capsulatus. J Am Chem Soc 123:10123-10124. https://doi.org/10.1021/ja016258m

Un S, Tabares LC, Cortez N, Hiraoka BY, Yamakura F (2004) Manganese(II) zero-field interaction in cambialistic and manganese superoxide dismutases and its relationship to the structure of the metal binding site. J Am Chem Soc. 126(9):2720-2726. https://doi.org/10.1021/ja036503x

Vagin AA, Steiner RA, Lebedev AA, Potterton L, McNicholas S, Long F, Murshudov GN (2004) REFMAC5 dictionary: organization of prior chemical knowledge and guidelines for its use. Acta Crystallogr D Biol Crystallogr 60:2184-2195. https://doi.org/10.1107/ S0907444904023510

Vermes I, Haanen C, Steffens-Nakken H, Reutelingsperger C (1995) A novel assay for apoptosis Flow cytometric detection of phosphatidylserine expression on early apoptotic cells using fluorescein labelled. Annexin V J Immunol Methods 184:39-51. https://doi. org/10.1016/0022-1759(95)00072-i

Vieceli Dalla Sega F, Zambonin L, Fiorentini D et al (2014) Specific aquaporins facilitate Nox-produced hydrogen peroxide transport through plasma membrane in leukaemia cells. Biochim Biophys Acta 1843:806-814. https://doi.org/10.1016/j.bbamcr.2014.01. 011

Winn MD, Isupov MN, Murshudov GN (2001) Use of TLS parameters to model anisotropic displacements in macromolecular refinement. Acta Crystallogr D Biol Crystallogr 57:122-133. https:// doi.org/10.1107/s0907444900014736

Ysebaert-Vanneste M, Vanneste WH (1980) Quantitative resolution of $\mathrm{Cu}, \mathrm{Zn}-$ and $\mathrm{Mn}$-superoxide dismutase activities. Anal Biochem 107:86-95. https://doi.org/10.1016/0003-2697(80)90496-0

Publisher's Note Springer Nature remains neutral with regard to jurisdictional claims in published maps and institutional affiliations. 